\title{
Fra krisemaksimering til kriseminimalisering
}

\author{
Ved Sara Germans, Ingun Haug, Eivind Olav Kjelbotn Evensen, Hanne Solhaug og Audun Fløgum Ørjasæter
}

\section{Modell for håndtering av akutt krise og kronisk suicidalitet hos pasienter med emosjonelt ustabil personlighetsforstyrrelse}

\begin{abstract}
Vi beskriver implementering av en trappetrinnsmodell i krisehåndtering for pasienter med emosjonelt ustabilt personlighetsforstyrrelse (EUPF) ved Psykiatrisk avdeling, Sykehuset Namsos, hvor hovedmålet er å understøtte den langsiktige psykoterapeutiske behandling. Vi beskriver forskjellige faser av modellen sammen med de utfordringer man har hatt knyttet til gjennomføringen av disse, relatert til sengpostnivå, klinikknivå, sykehusnivå og i førstelinjetjenesten. Våre hovedfunn er at fra 2007-2011 har det vært en nedgang i antall (re)innleggelser. Gjennomsnittlig innleggelsestid er blitt redusert. Bruk av tvangstiltak under innleggelse er synkende. Drøfting av resultatene og prosessen med å innføre trappetrinnsmodellen og de erfaringer man har sett på som betydningsfulle er gjort til slutt.
\end{abstract}

We describe an implementation of a step model of crisis management for patients with a borderline personality disorders (B-PD) at the Psychiatric Department, Namsos Hospital. The objective is to support the long-term psychotherapeutic treatment of the patients. We describe the different phases of the model along with the challenges linked to the implementation on the different levels in health care. Our main findings are that from 2007 to 2011 there was a reduction of (re)admissions of patients with B-PD. The average admission time has been reduced. The use of forced initiatives decreased. The article ends with a discussion of the implementation process of the model and the current significant experiences with the model.

LEVERT: 07/05-12 REVIDERT: 05/11-12 AKSEPTERT: 25/03-13

\section{Innledning}

\section{Empirisk og teoretisk bakgrunn}

Forekomsten av personlighetsforstyrrelse varierer innenfor normalbefolkningen mellom $10 \%$ til 14,8 \%, med en median på 13,5\%. Innenfor populasjon av psykiatriske pasienter, varierer forekomsten mellom 45,2 \% til 80,0 \% med en median på 60,4\%. Gjennomsnittlig antall personlighetsforstyrrelser per individ, er 2,3.

Emosjonell ustabil personlighetsforstyrrelse er den hyppigst diagnostiserte personlighetsforstyrrelsen med en median på 35,7 \%. Schizoid PF er den PF som har lavest prevalens med en median på 4,0 \% (Verheul, R., \&t van Den Brink, W.(1999).

Pasienter med emosjonelt ustabil personlighetsforstyrrelse har vansker med å nyttiggjøre seg av ett behandlingsopplegg som ikke er klart definert og har tydelig forutsigbarhet. Forskning viser at behandling uten definerte rammer og varighet resulterer i at $67 \%$ av pasientene med emosjonelt ustabil personlighetsforstyrrelse falt ut av behandlingen kort tid etter oppstart. Stort fokus på struktur og klare rammebetingelser er således viktige forutsetninger for å arbeide med denne pasientgruppen (Derksen, Benders \& Roverts 1998, Weinberg, Ronningstam, Goldblatt, Schechter, Maltsberger, 2011).

Både innhold og form i behandlingstilnærmingen er for øvrig beskrevet i retningslinjer fra American Psychiatric Association (APA, 2001), og i NICE guidelines fra 2009 (NICE, 2009). De omhandler blant annet kriseintervensjoner, sosialmedisinske tiltak, samarbeidsrutiner med involverte behandlere og aktiv informasjon til pasienter og pårørende. I tillegg foreligger det evidens for at Dialektisk atferdsterapi (DBT) og Mentaliseringsbasert terapi (MBT) har positiv effekt (Karterud, Wilberg \& Urnes, 2010), og at begge disse behandlingsmetoder etterstreber å ha ett langsiktig og strukturert rammefokus i den psykoterapeutiske prosess.

\section{Suicidalitet}

Det er svært viktig at man skiller mellom akutt og kronisk forhøyet suicidalrisiko, hvor den akutte suicidalrisikoen ofte relateres til kortvarig depresjon, rus, realitetsbrist eller dramatiske tapsopplevelser (Cavanagh, Carson, Sharpe, Lawrie 2003). Som beskrevet i retningslinjene for forebygging av selvmord i psykisk helsevern fra sosial- og helsedirektoratet er det viktig at man differensierer mellom akutt og kronisk forhøyet suicidalrisiko, da man bør unngå innleggelser i døgnenheter for pasienter med kronisk suicidalitet, og i stedet legge stor vekt på den langsiktige behandlingsplanen. Retningslinjene viser videre at akutte innleggelser ikke anbefales dersom pasienten er kjent, og at innleggelse vil føre til redusert behandlingsprognose gjennom endringer i den overordnede behandlingsplan. Dette betyr at både pasienten, pårørende og involvert helsepersonell må leve med noe større grad av risiko for suicidal atferd/selvdestruktiv atferd for denne gruppa, sammenliknet med pasienter med tidsavgrenset suicidalitet (2008).

Man bør således være forberedt på at selvmord vil kunne forekomme innenfor denne pasientgruppen og drive psykoedukativt arbeid med informasjon om at tilfeller av suicid vil kunne forekomme uten at behandlingsapparatet har gjort noe feil (Stangeland, 2012).

Frivillighet er essensielt gjennom ansvarliggjøring for å øke pasientens opplevde egenmestring. Som beskrevet i høringsdokument Norges Offentlige Utredninger (NOU) Økt selvbestemmelse og rettsikkerhet, er ansvarliggjøring og hjelp til å ta ansvar for eget liv sentralt i en terapeuts holdning overfor pasienter med alvorlig personlighetsforstyrrelse (PF). Ved for omfattende bruk av tvang vil man i stedet frata pasienten autonomi og beslutningskompetanse (2011). 
Med disse rammebetingelsene vil man i mindre grad ha fokus på pasientens stadige aktualiserte symptomer, men i større grad på hvordan pasienten håndterer sine emosjonelle utfordringer. Dette krever dog at terapeuten selv føler seg trygg til å tåle de emosjonelle belastninger som betinges av å kunne hjelpe pasienten i å tone ned det aktualiserte symptomfokus. På denne måten kan man si at ansvarliggjøringen og autonomistyrkingen av en pasient med emosjonelt ustabil personlighetsforstyrrelse krever en ansvarlig og autonom terapeut.

I denne forbindelse vil vi kort referere til Stangeland som i sin artikkel "Når sikreste behandling ikke er beste behandling" viser til at pasientene trenes "til å tåle usikkerhet og emosjonelle belastinger uten å reagere panisk med å flykte fra situasjonen. De samme kvaliteter kreves av behandleren" (side 144, 2012).

\section{Lokalisering}

Psykiatrisk sengepost i Namsos som kasus fra 2007

Den faglige virksomheten ved Akutt-og Allmennpsykiatrisk sengepost, Sykehuset Namsos, var i 2007 preget av manglende fokus på gjeldende retningslinjer for behandling av ulike psykiatriske lidelser. I tillegg manglet sengeposten en overordnet behandlingsfilosofi. Dette førte sannsynligvis til at forskjellige pasienter med sammenfallende diagnoser og patologi kunne motta svært ulik behandling avhengig av hvem som var pasientansvarlig behandler og deltagende i behandlingsteamet.

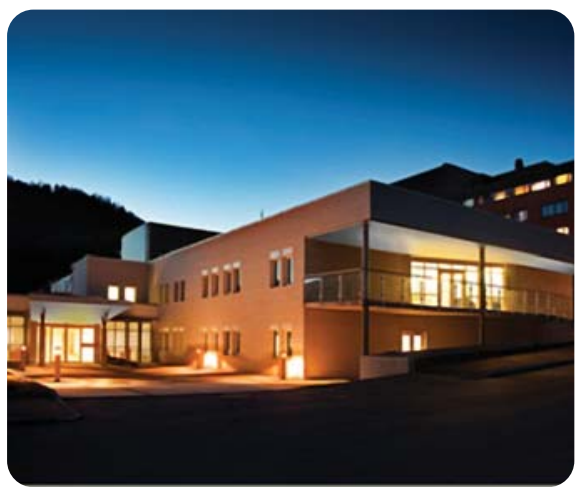

Psykiatrisk klinikk, Sykehuset Namsos
Mange av innleggelsene i sengeposten kunne ofte ha stort fokus på aktuelle symptomer og i mindre grad omhandle forståelse av pasientens grunnleggende patologi og personlighetsstruktur, noe som særlig gjorde seg gjeldende overfor pasienter med PF innenfor Cluster B. (hentet fra DSM-IV og innbefatter borderline PF (korrelerer med emosjonelt ustabil personlighetsforstyrrelse), antisosial PF, dramatiserende PF og narsissistisk PF (DSM-IV TR, 2000)).

I 2007 hadde sengeposten 55 innleggelser fordelt på 28 pasienter innen denne diagnosegruppe. Gjennomsnittlig liggetid for disse pasientene var 10 døgn, hvor lengste innleggelse var 76 døgn.

Symptomfokuset i behandlingen førte sannsynligvis til at pasientene i stor grad ble frarøvet autonomi og ansvar for egen fungering, noe som førte til økende grad av kontrollerende og restriktive tiltak som fastvakt, fotfølging, reimlegging og skjerming i forsøk på å hindre pasientene i deres selvdestruktive forsøk på selvregulering gjennom f.eks. villet egenskade.

På vår avdeling ble resultatet dog ofte det motsatte; pasientenes patologiske symptomer økte gjennom utagering, hvorpå de kontrollerende og restriktive tiltak også økte. Den maktesløse avstanden mellom terapeut og pasient ble herigjennom lengre på grunn av dette negative samspillet, og pasienten ble ikke engasjert i egen behandling. På denne måten vil man kunne hevde at sengepostens behandlingstilbud til denne pasientgruppen ikke hjalp pasientene, men tvert imot forsterket deres patologiske mønstre og vansker med selvregulering.

På samme tid oppsto ulike parallellprosesser hvor personalgruppen ble splittet og uformelle grupper med ulik patologiforståelse utviklet seg, noe som førte til $\emptyset k t$ sykefravær, samt mistillit til formell og faglig ledelse.

I Namsos forelå det et behov for å endre den gjeldende kliniske praksis og herunder sikre pasientene mer standardisert behandling i tråd med gjeldende nasjonale og internasjonale retningslinjer.
Denne endringsprosessen ble påbegynt våren i 2009 og har ingen sluttdato. Det betyr at prosessen fortsatt er virksom i dag.

Namsos er et relativt lite sted med cirka 41500 innbyggere i vårt nedslagsområde. Dette fører til at man har gode muligheter til å kunne etablere sterke samarbeidsrutiner rundt pasientgruppen, og har ført til at vi har utviklet en trappetrinnsmodell for håndtering av kriser med særlig fokus på samhandling, forståelse og kommunikasjon mellom de ulike involverte parter ved pasienten med en EUPF-diagnose.

\section{Metoden}

Vår endringsprosess har vært inndelt i 5 faser:

1. Utvikle en trappetrinnsmodell for krisehåndtering av pasienter med EUPF, med oppstart vinteren 2008.

2. Implementere modellen internt i egen avdeling ved Seksjon for akutt- og allmennpsykiatri i Namsos (SAAP), oppstart våren 2009.

3. Implementere modellen, samt gi veiledning om denne i Psykiatrisk klinikk ved Sykehuset Namsos, dvs. gjøre modellen godt kjent overfor andre seksjoner i klinikken (Allmennpoliklinikk, Seksjon for Psykose, Seksjon for Alderpsykiatri, Avdeling for rusrelatert psykiatri, nærliggende DPS osv.), oppstart høsten 2009.

4. Implementere modellen i samarbeid med somatiske avdelinger og blant aktører i primærhelsetjenesten (fastleger, lokal rus- og psykiatritjeneste osv.), og gi veiledning om denne, oppstart vinteren 2009.

5. Evaluering av nye praksis ved parametre som innleggelsestid, antall innleggelser, restriktive tiltak, bruk av tvang, selvskadelig atferd, retrospektiv fra 2007.

I samarbeid ved vaktapparat, seksjon Forsknings og Fagutviklingsenhet (FFE) og forskjellige seksjoner på sykehuset Namsos har man utviklet en trappetrinnsmodell (se figur 1). 
Figur 1. Trappetrinnsmodell

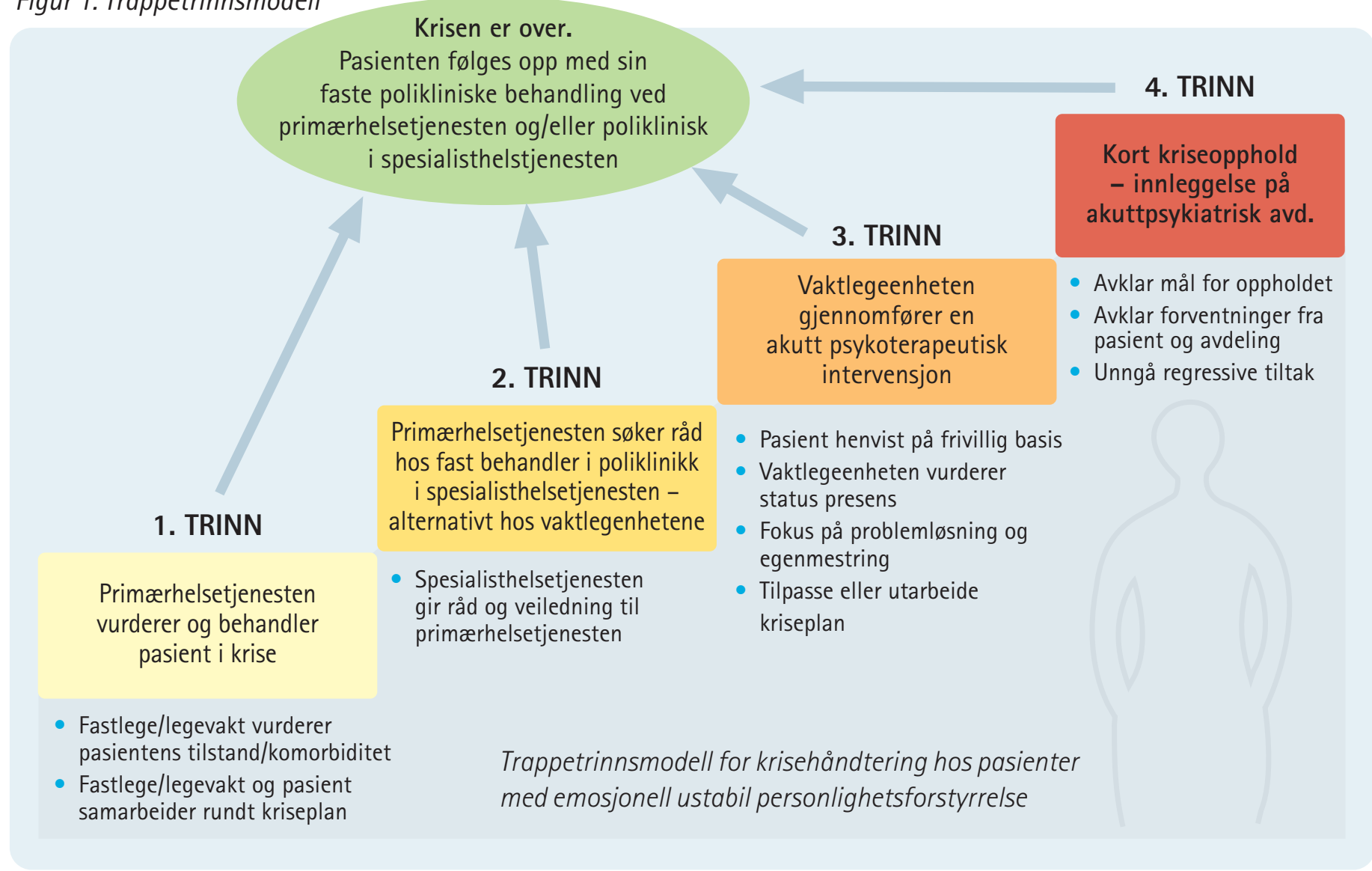

For å gjennomføre fase 2 (Implementering av modellen internt i egen avdeling SAAP) var det nødvendig å gjennomføre en større organisasjonsendring. Dette hadde sin bakgrunn i at de kliniske miljøer i avdelingen ofte var preget av betydelig "expressed emotions" og uformelle grupperinger med varierende grad av lojalitet til behandlingsmessige beslutninger. "Expressed Emotions" er et utrykk for negative følelser, for eksempel sinne eller fiendtlighet uttrykt av familiemedlemmer eller signifikante andre (APA, thesaurus of Psychological Index Term, 7th ed).

Det ble derfor gjennomført en kunnskapsbasert organisasjonsutviklingsprosess med fokus på ansvarliggjøre hver enkelt for å oppdatere seg ift. fag, og engasjere seg ift. sin egen arbeidsplass.

Prosessen ble gjennomført på både gruppe- og individnivå: Man gjennomførte 6 obligatoriske gruppesamlinger annenhver uke à 3 timer med samtlige 55 ansatte. I etterkant av dette har en kompetansegruppe bestående av 6 ansatte arbeidet med å kontinuere prosessen. I tillegg har både behandlere og miljøterapeuter vært engasjert i statistisk kartleggingsarbeid for å måle endringer i antall innleggelser, liggetid og symptomtrykk gjennom GAF, slik at man kunne monitorere prosessens progresjon, utfall og konsekvenser og herunder sørge for at flest mulig ansatte i sengeposten kunne oppleve at forandringsprosessen var meningsfull.

For å globalisere resultatene fra forandringsprosessen har man i tillegg fått tildelt ressurser til å bruke prosessen i videre skolering som ved masteroppgaveskriving, diverse undervisning og kongressfordrag, artikkelskrivning og posterproduksjon, noe som resulterte i posterpris ved Nasjonale Konferanse i Akuttpsykiatri i 2012.

I tillegg har resultatene fra prosessen ført til at man har laget en omfattende visjonsbeskrivelse for sengeposten SAAP hvor både behandling og ressursstyring i sengeposten er regulert med utgangspunkt i foreliggende retningslinjer for behandling og foreliggende mandatbeskrivelser for sengepostens virke. Dette for å unngå tilfeldig pasientbehandling og tilfeldig ressursstyring.
For å implementere fase 3 og 4 (implementering i klinikken for øvrig, somatiske avdelinger og i primærhelsetjenesten) har man gjennomført en rekke tiltak:

1. Internundervisning for de andre seksjoner ved psykiatrisk klinikk, undervisning for kommunale aktører, undervisning for alle fastleger, samt undervisning ved somatiske avdelinger som for eksempel akuttmottagelse, kirurgisk avdeling, medisinsk avdeling og intensivavdeling.

2. Etablere strukturerte møter med eget vaktlegeapparat for å diskutere pasientkasuistikker.

3. Lage informasjonsbrosjyre som beskriver avdelingen og den behandling som tilbys. Brosjyren er ment for både samarbeidspartnere i førstelinjetjenesten, andrelinjetjenesten, for pasienten selv og for pårørende.

4. Etablere faste maler for kriseplan (selvhjelpsplan) slik at disse er mest mulig like for alle involverte parter. 


\section{Materiale}

\section{Trappetrinnsmodell for krisehåndtering av pasienter med emosjonelt ustabil personlighetsforstyrrelse}

Bakgrunnen for utviklingen av trappetrinnsmodellen (se figur 1) er fundamentert i et ønske om å innta en bevisst holdning til hvilken behandling pasientene med emosjonelt ustabil personlighetsforstyrrelse vil motta i eventuelle krisesituasjoner, samt gi pasienten en gradert behandling hvor hovedmålet er å understøtte den langsiktige behandling uten nødvendigvis å sette i gang akutte tiltak:

\section{1.trinn:}

Hver gang primærhelsetjenesten møter en pasient med emosjonelt ustabil personlighetsforstyrrelse som er i krise vil de vurdere pasientens tilstand i forhold til eventuell komorbiditet. Herigjennom forsøker de å etablere/følge hans/hennes kriseplan for å redusere symptomtrykket av den opplevde krisen, noe som på samme tid kan gi grunnlag for økt mestring hos pasienten og primærhelsetjenesten. Hvis pasientens komorbide symptomer er i form av en åpenbar psykotisk tilstand eller alvorlig depresjon med selvmordsrisiko skal legevakt eller fastlege vurdere tilstanden utenfor trappetrinnmodellen. Det overordnede ønskelige utfallet av intervensjonen vil være at pasienten fortsetter sitt polikliniske behandlingsløp ved primærhelsetjeneste og/eller spesialisthelsetjeneste uten ytterligere akuttpsykiatriske intervensjoner med fokus på akutt symptomatologi.

\section{2. trinn:}

Ved mer uklare tilstander oppfordres primærhelsetjenesten i form av fastlege eller legevakt til å konferere med spesialisthelsetjenesten. Som hovedregel vil vi herunder anbefale at legen tar kontakt med pasientens faste polikliniske behandler, da denne behandleren kan gi best informasjon om behandlingsløpet, samt råd og veiledning vedrørende pasienten og vedkommendes behandling. $0 \mathrm{~m}$ dette ikke er mulig, er kontakt med vaktlegeenheten ett alternativ.
Veiledningen vil som regel ha to fokusområder:

A) Kartlegging av den aktuelle situasjon og tilstand, validering av primærhelsetjenestens situasjon, samt bistå med informasjon, råd og veiledning som forsøk på å dempe den opplevde krise og stimulere til økt mestring.

B) Hvis det foreligger behov for oppfølgingskontakt med legen etter forsøk på intervensjon, tilbys dette hvor saken drøftes og intervensjon evalueres.

Det overordnede ønskelige utfallet av intervensjonen vil være at pasienten fortsetter sitt polikliniske behandlingsløp ved primærhelsetjeneste og/eller spesialisthelsetjeneste uten ytterligere akuttpsykiatriske intervensjoner med fokus på akutt symptomatologi.

\section{3. trinn:}

I de tilfeller der tiltak i primærhelsetjenesten ikke har ført frem er det aktuelt med henvisning til spesialisthelsetjenesten. Ved å tilby vurderingssamtaler ved psykiatrisk vaktlegeenhet fremfor å avtale direkte innleggelse via primærlege/fastlege gir man signaler om at denne opplevde krisen ikke nødvendigvis utløser behov for innleggelse i sengepost. Frivillighet vurderes herunder som ett essensielt fundament for å kunne ansvarliggjøre pasienten og herunder rede grunnen for $ø k t$ opplevelse av egen mestring.

Under vurderingssamtalen vil man ha fokus på å kartlegge situasjonen og slik gå gjennom pasientens kriseplan med fokus på å redusere pasientens kontrolltap og opplevelse av krisen.

Det vil også være stort fokus på struktur i denne kontekst hvor tidsrammen for den akutt psykoterapeutiske intervensjon er satt til cirka 45 minutter og gjennomføres av en erfaren fagperson i vaktlegeenheten. Om det fortsatt foreligger usikkerhet vedrørende tilstanden anbefales det at fagpersonen søker etter veiledning og informasjon, samt snakker med pasienten på nytt i 45 minutter. Det vil i disse tilfeller ofte være ønskelig at enten poliklinisk pasientansvarlig behandler deltar eller spesialist i psykiatri/klinisk voksenpsykologi.

I vurderingssamtalen vil man etterstrebe å validere pasientens følelser gjennom empatisk lytting, ansvarliggjøre han/henne gjennom forsterking av konstruktiv symptomhåndtering og redusere fokuset på selvdestruktiv atferd. Som Paris nevner i boka Half in love with death (2007), er det viktigere at terapeuten reflekterer og viser empati, enn at terapeuten skal sette i gang akutte tiltak. Under selve vurderingssamtalen vil hovedfokuset være på nåtiden med aktiv bruk av pasientens kriseplan, og aktiv engasjering av pasienten i sin egen behandling, samt at man vil forsøke å involvere pårørende.

Det overordnede ønskelige utfallet av intervensjonen vil være at pasienten fortsetter sitt polikliniske behandlingsløp ved primærhelsetjeneste og/eller spesialisthelsetjeneste uten ytterligere akuttpsykiatriske intervensjoner med fokus på akutt symptomatologi.

\section{4. trinn:}

Om punktene 1,2 og 3 ikke har ført til krisereduksjon, vil det være aktuelt å tilby pasienten et kort kriseopphold på akuttavdelingen. Før man effektuerer dette vil man imidlertid lage en målsetning med oppholdet sammen med pasienten. I denne forbindelse vil pasientens forventninger til avdelingen fremkomme, og avdelingens forventninger til pasienten vil tydeliggjøres, i tillegg blir det beskrevet at pasienten vil skrives ut av avdelingen om han/hun ikke makter å nyttiggjøre seg oppholdet på en konstruktiv måte.

Som hovedregel er et kriseopphold av tre dagers varighet med ingen eller liten bruk av restriktive tiltak som skjerming etc. Under oppholdet vil man videre arbeide aktivt med å utarbeide kriseplan eller tilpasse en eventuell allerede foreliggende plan. Det vil ikke gjennomføres noen endringer av allerede etablert poliklinisk behandlingsopplegg, da dette vil kunne føre til uklare rammebetingelser for hvilken arena som er den bærende for pasientens overordnede behandling. 
Denne trappetrinnsmodellen er kun gjeldende for pasienter som er diagnostisert med emosjonelt ustabil personlighetsforstyrrelse og samtidig er i et behandlingsforløp. Ikke alle pasienter med denne problematikk makter å stå i ett slikt forløp, men kan allikevel oppleve kriser. Vi anbefaler imidlertid at man inntar den samme holdningen ved alle kriser, og at man sammen med pasienten evaluerer om det er ønskelig/nødvendig med et (nytt) fast behandlingsforløp.

\section{Kriseplan}

I denne forbindelse har utarbeidelsen av kriseplan vist seg å være nyttig. En kriseplan er en plan for å kunne reversere/avbryte negativ tankespiral tidligst mulig, slik at pasienten ikke kommer i en situasjon der vedkommende opplever uoverkommelig krise. Erfaringsmessig vil kort psykoedukasjon om en slik negativ spiral være med på å gi forståelse til pasienten samt bidra til økt deltakelse i selve arbeidet med å utarbeide kriseplanen. Selve kriseplanen består i hovedsak av tre punkter der man gjenkjenner og setter opp pasientens varselsignaler, tiltak og kontaktpersoner. Det finnes ulike varianter av kriseplaner også kjent under andre navn som for eksempel beredskapsplan. I vår klinikk heter kriseplan selvhjelpsplan.

Denne er laget med utgangspunkt i ulike allerede eksisterende kriseplaner (bl.a. Stanley og Brown, 2008).

I enkelte tilfeller vil forsøk med å utarbeide kriseplan sammen med pasienten ikke lykkes. I slike tilfeller er et minimum av innhold i en kriseplan å opplyse om legevakten og telefonnummeret dit. Også hos legevakten gjelder det at dersom pasienten kommer med en formulert forventning eller ønske, vil det være lettere å gi den hjelpen pasienten ønsker. Prosessen med å utarbeide kriseplanen er i langt større grad viktigere enn punktene på papiret. Det er viktig å understreke at dette er pasientens egen plan og at pasienten selv må ha troen på at punktene stemmer for dem selv, og at tiltakene vil fungere som planlagt.

Kriseplanen skrives ned, og det er viktig at pasienten har med seg en kopi av denne. En del av pasientene vil kunne huske enkelte punkter i kriseplanen, men faren for å glemme noen punkter og ikke etterleve planen er stor, dersom planen ikke er tilgjengelig. For å øke tilgangen til kriseplanen for pasienten, har man hatt god erfaring med enten å ta bilde av planen med mobiltelefonen eller å skrive over planen i en kriseplan som utformes som et laminert bankkort. Dette vil være med på å øke tilgjengeligheten fremfor et brettet A4-ark.

\section{Resultat}

Evalueringen av vår nye praksis har tatt utgangspunkt i data fra Pasient Administrativt System (PAS), og omfatter hoveddiagnosene i ICD-10, kapitel F60.X, som innebærer alle spesifikke personlighetsforstyrrelser, F61.X, blandede og andre personlighetsforstyrrelser, og F62.X, vedvarende personlighetsforandringer som ikke skyldes skade eller sykdom i hjernen. Følgende parametre ble undersøkt fra 2007 til 2011: antall pasienter, liggetid, gjennomsnittlig liggetid, antall reinnleggelser, selvskadelig atferd som har krevd behandling ved somatisk avdeling og reinnleggelser innen et år.

\section{Figur 2. Endringer ift. parametre på ressursbruk}

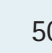

45

45

40

35

30

25

20

15

10

5

0

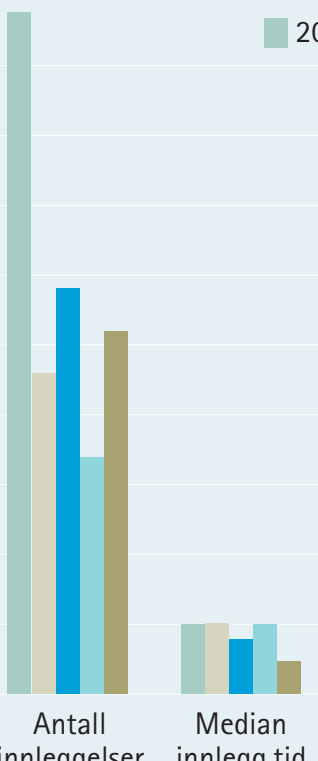

2007

2008

2009

2010

2011

Fra 2007 til 2011 var det en nedgang i antall innlagte pasienten med PF fra 27 i 2007 til 14 i 2011, antall innleggelser og gjennomsnittlig innleggelsestid fra 11.0 dager til 3.6 dager i 2011, antall reinnlagte pasienter gikk ned med 10 og antall selvskadelig adferd som trengte somatisk behandling på sykehuset gikk ned fra 6 til 3 tilfeller. (Se figur 2). Ift. restriktive tiltak er antall tvangsinnleggelser økt fra 3 til 5 , bruk av intervall eller kontinuerlig observasjon (KO/IO) ift. suicidalitet gikk ned til 1, mens skjerming, reimlegging og tvangsmedisinering ikke har forkommet 2011. (Se figur 2 og figur 3).

I tillegg evaluerte man iverksettelse av uerlig og intervallobservasjon, reimlegging eller tvangsmedisinering. For å evaluere 'expressed emotions' blant personalet ble

Fordi prosjektet innebærer evaluering av anbefalt praksis ut fra (inter)nasjonale retningslinjer ble det vurdert (i samråd med leder av Regional Etisk Komité (REK) at prosjektet ikke var framleggingspliktig for REK. 
Figur 3. Endringer ift. parametre på ressursbruk

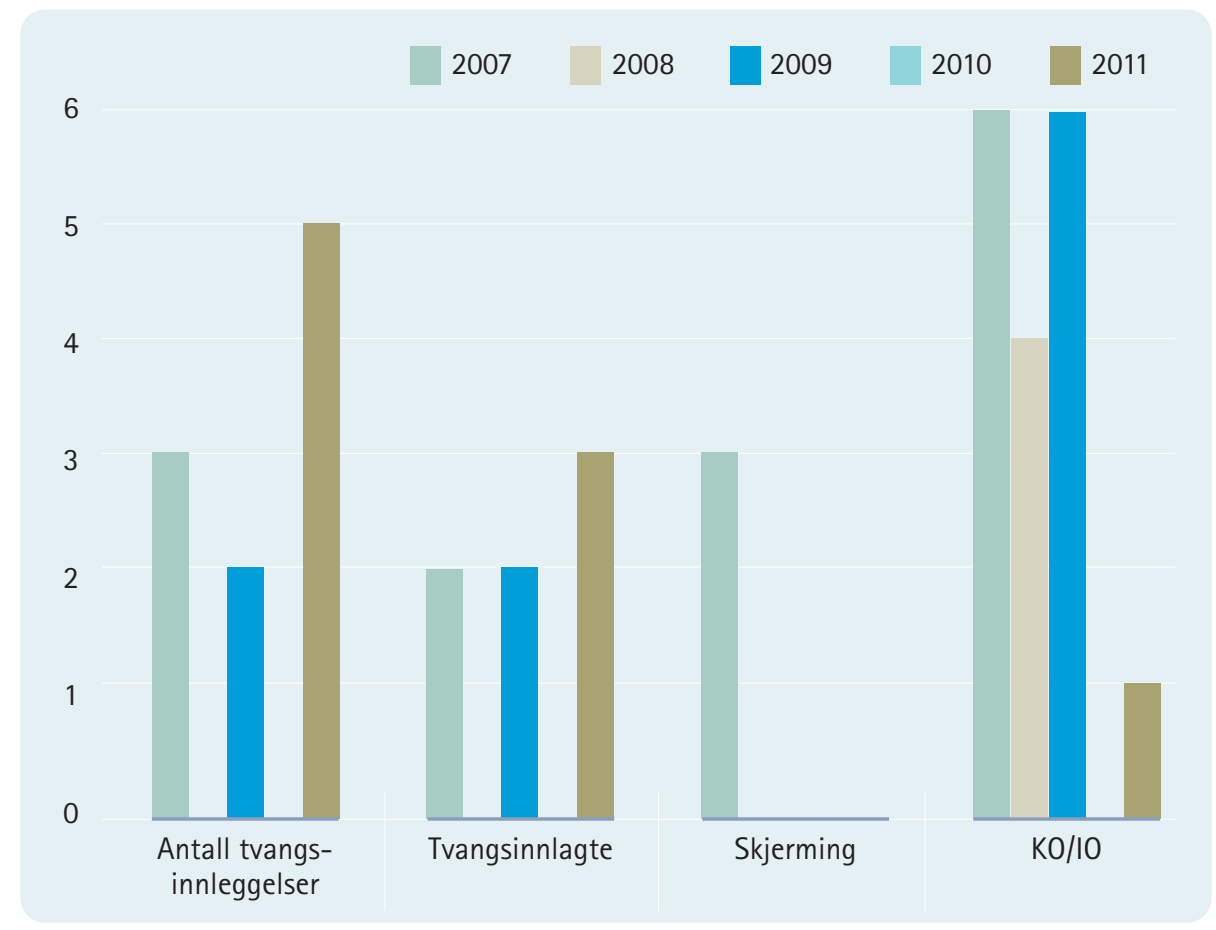

Et tydeligere fokus på trappetrinnsmodellen ser derfor ut til å ha medføt positive effekter som færre innleggelser, kortere innleggelsestid, mindre restriktive tiltak, samt mer fokus på samhandling og langsiktig psykoterapeutisk behandling. Det har samtidig avdekket en del utfordringer som vi vil beskrive videre i diskusjonen.

I tillegg har fokus på autonomistyrkende tiltak bidratt til å gi flere fremgangsmåter i arbeidet med pasienten, og dette har bidratt til trygghet hos ansatte. Vi opplever i liten grad at det blir "innrop" fra "sidelinjen" fra annet personal som ikke er i gruppen som arbeider med pasienten.

Vi klarer i tillegg å holde et økt fokus på en strukturert og enhetlig tilnærming, og har sett at graden av splitting og "expressed emotions" blant personalet på posten er redusert. Det er blitt gjennomført en arbeidsmiljøundersøkelse i 2008 og 2011, hvor arbeidsglede har blitt målt, den økte fra medium i 2008 til høy i 2011. Dette har også vist seg som en nedgang i antall sykemeldinger blant de ansatte, som gikk ned fra 15,6 til 9,0\%.

\section{Diskusjon}

Til tross for at det i dag foreligger betydelig forskningsmateriale og retningslinjer for behandling av denne PF er det svært krevende å lykkes i behandlingen (Karterud, Wilberg, Urnes, 2010). Ved Psykiatrisk Klinikk sykehuset Namsos har vi utviklet en trappetrinnsmodell for håndtering av kriser ved pasienter med en emosjonelt ustabil personlighetsforstyrrelse-diagnose. Denne modellen er basert på nasjonale og internasjonale retningslinjer som er et hjelpemiddel for behandlingsapparatet.

Denne studien viser at vår endrede praksis har en tendens til færre akutte intervensjoner, uten at dette øker risikoen for reinnleggelse og selvskadende atferd. Datamaterialet er ikke stort nok til at det dreier seg om statistisk signifikante endringer, men man ser en trend. I tillegg understreker vi at Sykehuset Namsos er en liten organisasjon, og at tallene i datamaterialet kan være sårbare for andre endringer som skjer i den daglige driften ved sykehuset. Videre vil vi trekke fram at populasjonen som har blitt evaluert består av hele spektrum av PF, det er likevel en hovedvekt av pasienten innen diagnoseserammen av ustabil PF.

\section{Praktiske utfordringer med modellen}

Implementering og opprettholdelse av trappetrinnsmodellen har sine utfordringer, både innenfor akuttavdelingen og overfor samarbeidspartnere.

Man må holde alle ansatte faglig oppdatert, og dette vil være en pågående prosess som ikke kan ha et sluttpunkt. Dette gjelder både for å unngå at man faller tilbake til en ubevisst holdning og tilnærming til de prosesser denne pasientgruppen skaper i oss, og for at nyansatte skal tillegge seg grunnleggende psykopatologisk forståelse av lidelsen.

Man vil også ha behov for videre oppdatering og undervisning av de ulike samarbeidspartnere. Vi har i liten grad oversikt over endringer i primærhelsetjenesten, men det er viktig at behandlingstilnærmingen i hele behandlingskjeden er ensrettet. Støtte til primærhelsetjenesten er og blir en viktig faktor i arbeidet videre, i tillegg til å støtte fast poliklinisk behandler i hans/hennes fokus på bruk av kriseplanen.

Modellen krever også at erfarne terapeuter og erfarne spesialister samt bakvakter har et bevisst ansvar i forhold til å sikre at den terapeutiske forståelsen er førende for det arbeidet enn mindre erfarne terapeuter og forvakter skal gjøre. Dette kan blant annet innebære at de er med i akutte vurderingssamtaler, for å ha mulighet for akutt intervensjon med fokus på å styrke pasientens autonomi og tro på egen evne til å mestre situasjonen gjennom bruk av kriseplanen. Dette betyr at ledelsen bør være kjent med at praksis kan føre til økt bruk av spesialistressurser i og utenfor arbeidstid.

I forhold til miljøpersonell vil det være viktig at man legger forholdene til rette for at den miljøterapeutiske intervensjon står i samsvar med målsetningen for en eventuell kriseinnleggelse. Siden det har vært fokus på personlighetsforstyrrelser i postens undervisningsprogram har det også medført mer ensrettet tilnærming i sengeposten. Vårt inntrykk er at det har ført til at det miljøterapeutiske fokus i langt større grad er blitt rettet mot empatisk validering av pasientens symptomer, men 
på samme tid ansvarliggjøring av pasienten for å håndtere disse selv. Denne autonomistyrkende holdning har således som hensikt å forhindre regresjon under innleggelse. Dette krever stadig fokus på patologiforståelse og retningslinjer gjennom undervisning har personalet $\mathrm{i}$ posten fått økt kunnskap for interpersonlige prosesser samt bakgrunn for dette.

\section{Konklusjon og avslutning}

Resultatene ved bruk av trappetrinnsmodell ved psykiatrisk klinikk i Namsos har så langt vært lovende, med en reduksjon i bruk av akutte restriktive tiltak som tvangsmidler, kontinuerlig/intervallobservasjon, samt mindre "expressed emotions" i personalgruppen.

Det er imidlertid viktig å nevne at datamaterialet er samlet for å evaluere vår endrede praksis, og ikke som ledd i en forskningsprosess. Datamaterialet er heller ikke stort nok til å gi statistisk signifikante resultater. Man ser imidlertid en trend som tyder på at man etter innføring av trappetrinnmodellen ved psykiatrisk avdeling ved Sykehuset Namsos er i stand til å innta en bevisst holdning til hvilken behandling pasientene med emosjonelt ustabil personlighetsforstyrrelse vil motta i eventuelle krisesituasjoner, samt gi pasienten en gradert behandling hvor hovedmålet er å understøtte den langsiktige behandling uten å nødvendigvis sette i gang akutte tiltak.

Vi har i vårt endringsarbeid i Namsos erfart at det er mulig å gjennomføre store endringer i den akuttpsykiatriske behandlingstilnærmingen overfor pasienter med emosjonelt ustabil personlighetsforstyrrelse. Det autonome og overordnede behandlingsfokus er fundamentert i retningslinjene for behandling, og ved å implementere disse i dagens behandlingstilnærming har vi samtidig oppdaget at kulturen på sengeposten også er blitt mer autonom og overordnet, med stort fokus på egen selvregulering og intern interpersonell dynamikk. Med denne erfaringsbakgrunn vil vi anbefale alle klinikere å sette seg inn i gjeldende retningslinjer for behandling av pasienter med emosjonelt utstabil personlighetsforstyrrelse og stille seg selv og sine kolleger/ledere følgende spørsmål: Har jeg/vi et autonomt overordnet fokus i det kliniske arbeidet, og er jeg/vi godt nok selvregulert til å kunne bistå andre i deres arbeid med egne reguleringsvansker. God refleksjon!

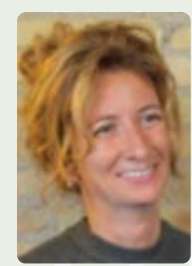

Sara Germans er utdannet psykiater i Nederland, overlege på akutt-/allmennpsykiatrisk sengepost, Sykehuset Namsos, fra 2008. Doktorgrad i 2011 om screeningsinstrumenter for personlighetsforstyrrelser. Har tidligere jobbet 4 år som psykiater på en lukket akuttpsykiatrisk avdeling i Nederland, og var i samme periode tilknyttet et akuttpsykiatrisk kriseteam.

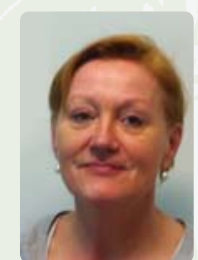

Ingun Haug er psykiatrisk sykepleier ved Psyk. avd, Sykehuset Namsos fra 1992. Har veiledningskompetanse i kognitiv terapi. Bred klinisk erfaring fra arbeid ved akuttpsykiatrisk sengepost, sengepost for psykoser og fra arbeid ved lærings- og mestringssenteret, Jobber nå ved FFE (forskning og fagutviklingsenheten) med organisering av interne og eksterne kurs, samt oppfølgning av forskningsprosjekter.

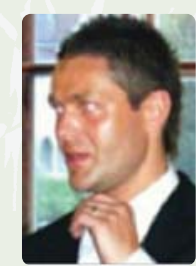

Eivind Olav Kjelbotn Evensen er psykologspesialist i akutt-। allmennpsykiatrisk sengepost og ansatt i vaktlegeenheten ved Sykehuset Namsos. Er i tillegg psykologfaglig rådgiver ved Sykehuset Namsos/Dps Kolvereid. Arbeidet 4 år ved voksenpsykiatrisk poliklinikk, 1 år ved barnepsykiatrisk ungdomsteam og 5 år ved akutt- og allmennpsykiatrisk sengepost.

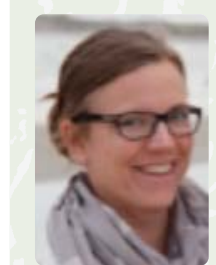

Hanne Solhaug er cand.med ved NTNU i 2006. Lege i Spesialisering ved psykiatrisk avdeling siden 2008.

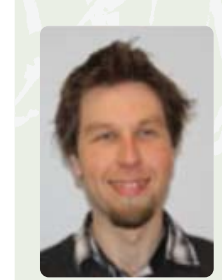

Audun Fløgum Ørjasæter er cand. Med ved UiTø 2003. Spesialisering i psykiatri ved St. Olavs hospital og Sykehuset Namsos. Jobbet i Namsos siden 2008. Spesialist i psykiatri siden 2011. Overlege ved Seksjon psykose, Psykiatrisk Klinikk, Sykehuset Namsos.

\section{Referanser}

American Psychiatric Association (1994). Diagnostic and Statistical Manual of Mental Disorders (fourth edition) (DSM-IV). Washington, DC: APA.

American Psychiatric Guidelines. (2001). http://web. unife.it/utenti/luigi.grassi/Linee\%20Guida\%20Psich iatria/American $\% 20$ Psychiatric\%20Association $\% 20$ Guidelines/Borderline\%20Personality\%20Disorders.pdf

APA, thesaurus of Psychological Index Term, 7. utg.

Brooner, R.K., King, V.L., Kidorf, M., Schmidt, C.W. Jr., \&t Bigelow, G.E. (1997). Psychiatric and substance use comorbidity among treatment-seeking opioid abusers. Archives of General Psychiatry, 54, 71-80.

Cavanagh J.T., Carson A.J., Sharpe M., Lawrie S.M. (2003). Psycological autopsy studies of suicide: a systematic review. Psychological Medicine 2003, 33(3), 395-405.

Derksen, J.J.L., Benders J. \& Roverts J. (1998). De psychologische behandeling van de borderline patient. Derksen, J.J.L \&t Groen H. (eds.) Handboek voor de behandleing van borderline patienten. (61-64).

Elsevier/de tijdstroom, Maarsen.

Harris, E.C., \&t Barraclough, B. (1997). Suicide as an outcome for mental disorders. A meta-analysis. British Journal of Psychiatry, 170, 205-28.

Hodgins, S., Mednick, S.A., Brennan, P.A., Schulsinger, F., \&t Engberg, M. (1996). Mental disorder and crime. Evidence from a Danish birth cohort. Archives of General Psychiatry, 53, 489-96.

Høring-NOU Økt selvbestemmelse og rettssikkerhet. Helse og omsorgsdepartementet. (2011). http://www.legeforeniging.no/Legeforenigingenmener/Horingsuttaleser/2011 horing-nou-2011:9.

Karterud S., Wilberg, T., Urnes, $\varnothing$ (2010). Personlighedspsykiatri. Oslo: Gyldendal Akademisk.

Mulder, R.T. (2002). Alcoholism and personality. Australian and New Zealand Journal of Psychiatry, $36,44-52$.

NICE-Guidelines. (2009). http://publications.nice. org.uk/borderline-personality-disorder-cg78.

Paris, J. (2007) Half in Love with Death: Managing the chronically Suicidal Patient. Routledge, Oxford, UK.

Rendu, A., Moran, P., Patel, A., Knapp, M., \&t Mann A.(2002). Economic impact of personality disorders in UK primary care attenders. British Journal of Psychiatry, 181, 62-6.

Sosial og helsedirektoratet. Nasjonale retningslinjer for forebygging av selvmord i psykisk helsevern, januar 2008, ISBN 978-82-8081-098-4, Oslo.

Stangeland S. (2012). Når sikreste behandling ikke er beste behandling. Tidsskrift for Norsk Psykologforening, 49, 139-44.

Stanley, B. \& Brown, G. (2008). Safety plan treatment manual to reduce suicide risk: veteran version. Verheul, R., \& van Den Brink, W.(1999). Persoonlijkheidsstoornissen. I De Jong, A., Van Den Brink, W., Ormel, J., \& Wiersma, D. P. (eds.). Handboek psychiatrische epidemiologie. (347-372). Utrecht: De Tijdstroom.

Weinberg I., Ronningstam E., Goldblatt M.J., Schechter M., Maltsberger J.T. (2011). Common factors in empirically supported treatments of borderline personality disorder. Curr Psychiatry Rep., 13(1), 60-8. 